\title{
Correction to: Analysis of food and fluid intake in elite ultra-endurance runners during a 24-h world championship
}

Chloé Lavoué ${ }^{1,2}$, Julien Siracusa ${ }^{1,2}$, Émeric Chalchat ${ }^{1,2}$, Cyprien Bourrilhon ${ }^{1,2}$ and Keyne Charlot ${ }^{1,2^{*}}$

Correction to: J Int Soc Sports Nutr 17, 36 (2020) https://doi.org/10.1186/s12970-020-00364-7

The original article [1] contained some minor errors in the reporting of sodium intake of three participants during the race.

The final paragraph of the Discussion section in the original article has been updated to correct the initial reporting of sodium intake from $49 \mathrm{~g}$ to $20.9 \mathrm{~g}$; associated errors in Fig. 2 and Table 3 have also been corrected.

Published online: 21 April 2021

\section{Reference}

1. Lavoué $\mathrm{C}$, et al. Analysis of food and fluid intake in elite ultra-endurance

runners during a 24-h world championship. J Int Soc Sports Nutr. 2020;17:36 https://doi.org/10.1186/s12970-020-00364-7.

The original article can be found online at https://doi.org/10.1186/s12970020-00364-7.

* Correspondence: keynecharlot@gmail.com

'Département Environnements Opérationnels, Institut de Recherche Biomédicale des Armées, Unité de Physiologie des Exercices et Activités en Conditions Extrêmes, 1 place Général Valérie André, 91223 Bretigny-Sur-Orge, France

${ }^{2}$ LBEPS, Univ Evry, IRBA, Université Paris Saclay, 91025 Evry, France

(c) The Author(s). 2021 Open Access This article is licensed under a Creative Commons Attribution 4.0 International License, which permits use, sharing, adaptation, distribution and reproduction in any medium or format, as long as you give appropriate credit to the original author(s) and the source, provide a link to the Creative Commons licence, and indicate if changes were made. The images or other third party material in this article are included in the article's Creative Commons licence, unless indicated otherwise in a credit line to the material. If material is not included in the article's Creative Commons licence and your intended use is not permitted by statutory regulation or exceeds the permitted use, you will need to obtain permission directly from the copyright holder. To view a copy of this licence, visit http://creativecommons.org/licenses/by/4.0/. The Creative Commons Public Domain Dedication waiver (http://creativecommons.org/publicdomain/zero/1.0/) applies to the data made available in this article, unless otherwise stated in a credit line to the data. 